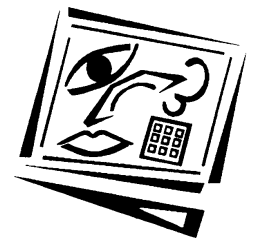

\title{
Examining preservice teachers' perceived knowledge of TPACK and cyberwellness through structural equation modeling
}

\author{
Ching Sing Chai, Joyce Hwee Ling Koh \\ Nanyang Technological University \\ Hsin Ning Jessie Ho, Chin-Chung Tsai \\ National Taiwan University of Science and Technology
}

\begin{abstract}
This study examined outcomes from an information and communication technology (ICT) course designed on the basis of the meaningful learning framework and general cyberwellness issues. It also examined the relationships among Singaporean preservice teachers' perceptions of the constructs pertaining to technological pedagogical content knowledge (TPACK), and their perceived ability to integrate cyberwellness knowledge when designing web-related learning. Two questionnaires were administered to 668 and 628 preservice teachers before and after the ICT course to elicit the relationships. Five TPACK knowledge constructs (PK, CK, Web 2.0-related TK, TPK, TPACK) and the teachers' cyberwellness knowledge were identified from factor analysis results. The pre-post course surveys indicate that the preservice teachers perceived strong gain in 5 out 6 constructs measured. Additionally, the structural equation model analysis revealed that cyberwellness knowledge contributes significantly to TPK and TPACK, based on the preservice teachers' perception. As such, the study argues that the preservice teachers' confidence to integrate their cyberwellness knowledge into their teaching may play an important role in influencing how they plan and design web-based learning. Cyberwellness knowledge may be an important knowledge component to foster when considering the future development of teachers' TPACK for web-based learning.
\end{abstract}

\section{Introduction}

With the explosion of new advances in information technology and digital devices, the impact of technology changes the way that teaching and learning takes place. As technology becomes more pervasive, the challenge for teachers to integrate technology into instruction is no longer based on the viability of technology-based learning but is shifted to a decision about when to use the technology and how to use it for more effective educational experiences (Neal \& Miller, 2006). Recently, innovative webbased technologies and social networking tools (also called Web 2.0 tools) are applied to different teaching contexts by building student-teacher learning communities, sharing educational resources, and enhancing mutual communications that promote constructivist-based collaborative learning approaches (Bull, Hammond \& Ferster, 2008; Purdy, 2010). With such approaches, students act as active learners to seek relevant resources, build cognitive artifacts, exchange information and feedback, and complete the assigned tasks collaboratively. The adoption of web-based technologies in academic learning creates an innovative learning environment and establishes 
connection to students' life. Consequently, teacher preparation and development program should investigate how to design effective courses to assist teachers in acquiring knowledge to capitalise upon these affordances in their teaching practices (Ajjan \& Hartshorne, 2008).

While the web-based technologies provide more efficient access for collaborative pedagogy and have extended tremendous opportunities for learners to enrich their knowledge pursuits (Greenhow, Robelia \& Hughes, 2009), they also present a number of potential threats to inexperienced users, especially school children. These threats include exposure to inappropriate or potentially dangerous information, inappropriate disclosure of important and private information, cyber bullying, Internet addiction, sex solicitation and online email scams (Bulter, 2010; Lim, 2010). Studies have shown that while educators acknowledge the benefits of applying web-based tools to teaching, they were hesitant to embrace the technology due to potential cyber risks and the lack of cyberwellness knowledge training support (Bumgardner \& Knestis, 2011; Maranto \& Barton, 2010). As a result, the ability of teachers to integrate web-based tools for enhanced learner-centered experiences, while avoiding these risks, becomes a crucial topic to consider in teacher education program (Endicott-Popovsky, 2008).

This study examines the effectiveness of an ICT course designed for Singaporean preservice teachers to integrate the use of Web 2.0 tools in the classroom, with adequate consideration of cyberwellness issues. The study adopted Mishra and Koehler's (2006) notion of technological pedagogical content knowledge (TPACK) as the ICT course design model to develop preservice teachers' TPACK knowledge for incorporating Web 2.0 tools into their teaching practices. In this course, one of the objectives addressed the issues related to safe and ethical use of the web-based technologies, which are referred here as cyberwellness issues. Cyberwellness issues are regarded as necessary elements to be considered when preservice teachers are designing web-based learning. We examined how preservice teachers' perceived TPACK and cyberwellness knowledge changed, before and after the course. In addition, we tested the relationship between the TPACK constructs and cyberwellness knowledge through structural equation modeling.

\section{Literature review}

\section{The TPACK framework}

To analyse how teachers effectively integrate the technology into teaching, Mishra and Koehler (2006) proposed a TPACK model (technological pedagogical content knowledge) based on Shulman's (1986) PCK (pedagogical content knowledge) theory. PCK viewed teachers' pedagogical knowledge and content knowledge as one integrated unit that could not be isolated from one another. Effective teaching is contingent upon teachers' abilities to represent and formulate the subject matter so that it is comprehensible and accessible to students. By extending this framework, TPACK includes technology as an additional knowledge construct, and proposes that effective teaching with technology needs to focus on the connections and interactions among subject content, pedagogy, and technology. Teachers with highly developed TPACK are more likely to design lessons that successfully integrate ICT into the teaching of subject matter (Chai, Koh, Tsai \& Tan, 2011; Koehler \& Mishra, 2005; Marino, Sameshima \& Beecher, 2009). Table 1 presents the definition of each knowledge construct in the TPACK model, including PK (pedagogical knowledge), CK (content 
knowledge), and TK (technological knowledge); with four intersected knowledge constructs: pedagogical content knowledge (PCK), technological content knowledge (TCK), technological pedagogical knowledge (TPK), and technological pedagogical content knowledge (TPACK).

Table 1: The definitions of knowledge constructs of TPACK model

\begin{tabular}{|l|l|}
\multicolumn{1}{|c|}{ Knowledge constructs } & \multicolumn{1}{c|}{ Definitions } \\
\hline Content knowledge (CK) & knowledge about the subject matter \\
\hline Technology knowledge (TK) & knowledge about technologies \\
\hline Pedagogical knowledge (PK) & knowledge about the process or methods of instruction \\
\hline $\begin{array}{l}\text { Technological content knowledge } \\
\text { (TCK) }\end{array}$ & $\begin{array}{l}\text { knowledge to represent the content or the subject matter } \\
\text { with technology }\end{array}$ \\
\hline $\begin{array}{l}\text { Technological pedagogical } \\
\text { knowledge (TPK) }\end{array}$ & $\begin{array}{l}\text { knowledge of the existence, components, and capabilities } \\
\text { of various technologies to be used in teaching }\end{array}$ \\
\hline $\begin{array}{l}\text { Pedagogical content knowledge } \\
\text { (PCK) }\end{array}$ & $\begin{array}{l}\text { knowledge of pedagogical strategies to teach specific } \\
\text { content (subject matter) }\end{array}$ \\
\hline $\begin{array}{l}\text { Technological pedagogical content } \\
\text { knowledge (TPACK) }\end{array}$ & $\begin{array}{l}\text { knowledge of using technologies to teach and represent } \\
\text { the subject matter }\end{array}$ \\
\hline
\end{tabular}

Since the TPACK framework was developed as a theoretical foundation to provide insights about quality teaching with technology, teacher education programs started to adapt the theory to design curriculum for preparing preservice and inservice teachers to integrate technology for teaching and learning (Chai, Koh \& Tsai, 2010; Jimoyiannis, 2010). As the framework became more widely recognised in teacher education (AACTE, 2008), researchers began to put their effort into identifying how teachers' TPACK is developed. Learning by design has been identified as the main pedagogical approach in which preservice and inservice teachers can develop improved understanding about how to integrate technology in classroom (Angeli \& Valanides, 2009; Chai et al, 2011; Mishra \& Koehler, 2006; So \& Kim, 2009; Tee \& Lee, 2011). In essence, learning by design involves teachers in considering how technology, pedagogy and content knowledge can be synthesised to design specific lessons for students' learning. Teachers' initial view of technology, pedagogy, and content knowledge as separate entities gradually shifted towards the integrated view about the three knowledge constructs through the lesson design process (Angeli \& Valinides, 2009).

A recent review of 74 published empirical studies employing the TPACK framework did not surface any attempt by researchers to link cyberwellness issues as part of the TPACK framework (Chai, 2011). This is despite the fact that many researchers recognised that TPACK is a highly situated form of knowledge derived through teachers' design efforts and that the broader classroom context shapes the manifestation of TPACK in classrooms (e.g., Doering, Veletsianos, Scharber \& Miller, 2009; Pierson \& Borthwick, 2010). We argue that cyberwellness is one of the important contextual factors that shape teachers' pedagogical decision when they design webbased learning. In other words, we see knowledge about cyberwellness as a unique form of knowledge related to the use of web-based technology for teaching (i.e., a form of TPK). Teachers should consider cyberwellness issues when they design web-based lessons. However, current literature has not paid sufficient attention to this area. 


\section{Cyberwellness and its impact on Web2.0 learning environments}

The emerging Web 2.0 technologies are becoming important Internet tools that people use for social interactions, collaborations, knowledge sharing and creation; examples of these tools include Facebook, wikis and blogs (Grosseck, 2009). Studies have shown that adopting Web 2.0 tools with instructions may improve interactions and communications between teachers and students (Cheon, Song, Jones \& Nam, 2010; Hartshorne \& Ajjan, 2009). Therefore, increasing teachers' TPACK to integrate Web 2.0 tools into their lessons has been emphasised in teacher professional development programs for achieving learning and teaching effectiveness (e.g. Archambault, Wetzel, Foulger \& Williams, 2010).

Despite reported efforts in teacher education to foster the use of Web 2.0 applications in classroom teaching and learning, teachers have reported frustration and uneasiness towards Web 2.0 learning contexts, due to cyberwellness issues. For instance, Sharples, Graber, Harrison and Logan (2009) surveyed 206 in-service teachers teaching children aged 11-16 to analyse their reactions about Internet safety issues with children's use of Web 2.0. They found that around half of the teachers had engaged students in Web 2.0 activities. However, $42 \%$ of these teachers had never taught students about online safety and only $11 \%$ did so frequently. In addition, $46 \%$ of the teachers reported that they had negative experiences caused by students using Web 2.0. On the other hand, Valcke, Schellens, Keer and Gerarts (2007) surveyed 78 primary school principals in Flanders and found that there was a general awareness of school policy to inform pupils about safe use of the Internet. However, the acquisition of specific knowledge or skills related to safe Internet use was not provided for. Beycioglu (2009) investigated 314 preservice teachers' perspectives on unethical computer use in Turkey and concluded that these teachers were sensitive to the ethical use of computers, but underestimated the importance of the issue. In short, some teachers and administrators are still not aware of cyberwellness issues and most of them do not receive enough support to acquire cyberwellness knowledge.

Web 2.0 has been acknowledged as efficient technologies for supporting and enhancing collaborative instructional strategies in learning (Wang \& Woo, 2009). However, the integration of Web 2.0 into classroom teaching and learning could be further enhanced if teachers are guided to handle cyberwellness concerns in the Web 2.0 environment. For example, Land and Bayne (2008) reported that in one of the studies they conducted, they found one instructor who used blogs (TK) for student reflection and giving student feedback (PK); however, each student's blog was open only to the tutor. The instructor explained that this practice (TPK) was beneficial in providing personal feedback to the student and protecting his/her online safety. With this case, Land and Bayne argued that the students did not actually experience collaborative learning, even the Web 2.0 tool was integrated into the lecture. Dohn (2009) also claimed that it is difficult to utilise wiki functions (TK) for students to "produce" materials for authentic use from learned knowledge, because students were able to publish articles without including references and original resources. Both cases illustrate teachers' struggles with web-based collaborative learning that could be remedied with appropriate lesson design which addresses cyberwellness concerns.

On the other hand, Chou and Peng (2011) reported that teachers in K-16 education who received e-safety training courses feel more comfortable about selecting and utilising Web resources for their instruction (TPACK), and have a positive attitude in 
guiding students with e-safety information in their instructional activities (TPK) and teaching materials (TCK) within the web-based environment. These results imply that cyberwellness concerns within Web 2.0 contexts restricted teachers' actual practices and influenced the effectiveness of Web 2.0-based curriculum design. Therefore, as "learning by design" is the key principle for developing teachers' TPACK knowledge, Nelson, Christopher and Mims (2009) advised that teachers should consider cyberwellness challenges when engaging TPACK-based, Web 2.0-integrated instructional design tasks.

In sum, studies have described that teachers' TPACK development is essential for effectively integrating Web 2.0 into their teaching practices. Research findings also indicate that teachers' Web 2.0 integration (e.g. TCK, TPK, TPACK) is influenced by teachers' understanding of cyberwellness knowledge - an important variable resulting from the characteristics of Web 2.0 contexts. However, as reviewed earlier, almost no studies were found to have examined whether the designing of learning in web-based lessons, undergirded by the TPACK framework and the learning of cyberwellness knowledge, can be carried out concurrently and effectively. In addition, how cyberwellness knowledge relates to teachers' TPACK constructs also has not been investigated. This study addresses these two gaps by using a TPACK survey to examine whether a pre-service teacher ICT course that incorporates cyberwellness into its lesson objectives related to web-based learning has any impact on teachers' TPACK. It proposes a hypothesised model showing the interrelationships among cyberwellness knowledge and TPACK constructs by utilising structural equation modeling to verify the relationships. This model enables insights into how teachers' perceptions and capability to include cyberwellness knowledge into their instructional practices relate to the TPACK framework in Web 2.0 learning contexts.

\section{Method}

\section{Research questions}

This study investigated two research questions:

1. How effective is the ICT course in enhancing preservice teachers' perceived understanding of the identified TPACK constructs and cyberwellness knowledge?

2. Is the hypothesised structural equation model acceptable in depicting the relationships between the identified TPACK constructs and cyberwellness knowledge?

To answer these two questions, the current study used web-based learning as the specific learning context and examined the participants' TPACK knowledge development after they completed an ICT course for learning how to integrate Web 2.0 tools into their lesson designs. It also included cyberwellness knowledge as another construct, which is believed to contribute to teachers' TPACK application, in showing how it relates structurally with teachers' TPK and TPACK constructs. Structural equation modeling was utilised to verify the framework structure and the relationships among each component. Figure 1 illustrates the hypothesised model among each TPACK and cyberwellness constructs. 
It is hypothesised that the Web 2.0-related TK, CK, and PK that teachers possess contribute positively to their TCK, PCK, TPK and TPACK. In addition, teachers' perceptions of their cyberwellness knowledge also contributes significantly to their TPK and their overall competence in designing web-based learning represented by the TPACK construct.

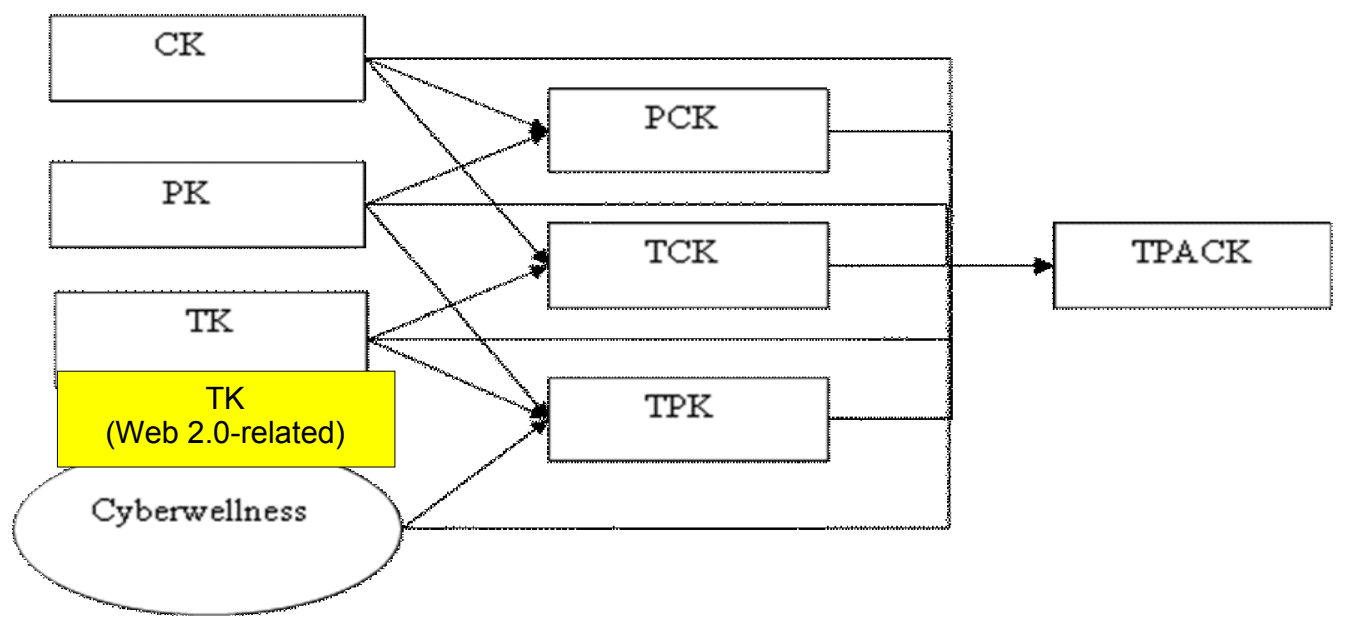

Figure 1: The hypothetical model of structural relations among content, pedagogy, web-related technology knowledge, and cyberwellness constructs

\section{Research context and participants}

The participants of this research were Singaporean preservice teachers who were completing their teacher certification in the first half of 2010. The participants were invited to complete an online questionnaire before and after they completed their compulsory ICT course. A total of 668 and 628 preservice teachers responded to the survey before and after the course respectively. About $35 \%$ of the respondents are male preservice teachers for both pre-and-post course surveys and about $47 \%$ of the respondents were primary school teachers. The survey was anonymous and voluntary in nature.

\section{The ICT course}

The ICT course entitled ICT for Meaningful Learning was designed to facilitate the preservice teachers' development of TPACK-related knowledge so that they are well prepared for ICT integration in the classrooms. The conceptual framework of the course is based on the notion of meaningful learning as articulated by Jonassen, Howland, Marra and Crismond (2008). The five key dimensions of meaningful learning with ICT include (1) challenging students with authentic problems; (2) empowering students to be intentionally self-regulated learners; (3) facilitating students' conversational and cooperative learning; (4) engaging students in active manipulation of objects being studied; (5) scaffolding students' constructive meaning making. These dimensions are actualised in the course through one group-based (3-4 in a group) and one individual-based project. The preservice teachers are tasked to 
design ICT-enhanced lessons that could facilitate K-12 students' collaborative and selfdirected learning supported by ICT.

We considered these projects as authentic problems for the preservice teachers. During the group projects, the preservice teachers are empowered to choose the topic and the ICT tools that they want to used, discuss and negotiate the intellectual and physical work needed, actively construct websites or digitised learning materials, and justify their design based on the meaningful learning framework. In other words, they experienced meaningful learning and based on their experience, they created meaningful learning for the students in their individual design project. Web-based technologies are treated as necessary tools to support the delivery of the preservice teachers-designed lesson. While the teacher educators demonstrate some basic skills, for example creating Google sites and using Google Docs for collaboration, this is not the main focus of the course. The preservice teachers are able to handle the technical skills quite independently. The teacher educators spent most of their time challenging and deepening preservice teachers' pedagogical reasoning as they facilitated the projectbased learning.

With regards to the understanding of cyberwellness issues, the preservice teachers were tasked to engage in self-directed learning, supplemented by prescribed readings and online resources. They were also encouraged to perform additional online and text-based research. Discussion forums were created for all the tutorial groups and the preservice teachers were to post their findings and questions, which were discussed over two weeks. Eventually, the preservice teachers had to design a series of lessons supported by ICT that help K-12 students to learn a particular cyberwellness topic such as dealing with inappropriate materials or cyber-bullying.

\section{The preservice teachers' TPACK knowledge assessment survey}

This study adopted the TPACK for Meaningful Web-based Learning Survey to measure preservice teachers' understanding of the seven knowledge domains (CK, PK, Web 2.0related TK, PCK, TCK, TPK, and TPACK), in response to Koehler and Mishra's (2005) assertion of the TPACK framework. The TPACK for Meaningful Web-based Learning Survey was developed based on previous work conducted by Chai et al. (2011) and Schmidt et al. (2009).

For the TPACK for Meaningful Web-based Learning Survey, PK and TPK items were adopted from Chai et al. (2011). The items in these two constructs reflect the course's pedagogical emphasis towards using ICT to facilitate meaningful learning as proposed by Jonassen et al. (2008). In addition, since the survey items developed by Schmidt et al. (2009) were targeted towards general technologies and various curriculum content (e.g. mathematics, social studies, science, literacy), the current study modified the survey questions by adding in TK items that were related to Web 2.0 technologies (e.g. blogs, wikis, Facebook, Skype). Overall, the TPACK survey was contextualised with designated PK, TPK, and Web 2.0-related TK items for the specific ICT course and the Web 2.0 learning context.

Forty six items were included in the survey and each factor contained at least 4 items (Appendix A). The rating range for all of the questions was from "strongly disagree" to "strongly agree" and presented in a 1-7 Likert scale. The score of "1" was rated for "Strongly disagree" while the score of "7" was rated for "Strongly agree". 


\section{The preservice teachers' perceived ability to guide students on cyberwellness issues survey}

The preservice teachers' judgment about their capability to include cyberwellness issues in their instructional practices was measured by four self-developed items (Appendix B). These survey items were also rated from "strongly disagree" to "strongly agree" in 1-7 Likert scale (1=strongly disagree and 7=strongly agree).

\section{Data analyses}

Exploratory factor analysis (EFA) was used to reduce the items for each survey. The pre-course survey was used for EFA. In the EFA, only items with factor loading values larger than .50 were retained in the refined questionnaires. After that, the present study employed confirmatory factor analysis (CFA) to clarify the model fit and the factor structure of the surveys based on the post-course survey. A test of internal consistency reliability (Cronbach's alpha) was conducted for the post-course survey.

Subsequently, the post-course survey was analysed for Pearson's correlation to examine the relationships among the five TPACK and one cyberwellness knowledge constructs and finally, a structural equation modeling analysis was employed to test each possible path in the hypothesised model as shown in Figure 1.

\section{Results}

\section{Factor analyses for preservice teachers' TPACK assessment}

A principal component analysis (exploratory factor analysis) was conducted with orthogonal rotation (varimax) to clarify the survey structure based on pre-course survey data. An initial analysis was conducted to obtain the eigenvalue for each component in the data. Five components had eigenvalues over Kaiser's criterion of 1 and were grouped into five factors (TPACK, Web 2.0-related TK, TPK, PK, CK). The items from TPACK, PCK and TCK loaded together to form the TPACK factor. Items with a factor loading value of less than .50 and with multiple cross-loadings were omitted from the survey. A total of 34 items were retained in the final questionnaire. The final selected items are presented in Appendix A.

Confirmatory factor analysis was then used to assess the model fit and confirm the convergent validity of the survey. The loading values of the survey items show significance $(p<.01)$ and are larger than .50 . In addition, the values of RMSEA $=.05$, $\mathrm{CFI}=.97, \chi^{2} /$ degree of freedom $=2.52$ indicate a reasonable model fit (Hair, Black, Babin, Anderson \& Tatham, 2006), indicating that the survey items have good convergent and construct validity. Table 2 presents the results of the confirmatory factor analysis.

As presented in Table 2, the Cronbach alpha value for each factor is above .9 and for the overall survey is .98 . The alpha values indicate good internal consistency of the survey items.

\section{Factor analyses for preservice teachers' perceived ability to guide students on cyberwellness issues}

Similarly, an exploratory factor analysis (by using pretest data) was conducted with orthogonal rotation (varimax) to clarify the survey structure of cyberwellness items. 
All of the four items were retained with factor loadings larger than .50 and they constituted only one factor for assessing preservice teachers' perceptions of their ability in instructing the cyberwellness issues to the students.

Table 2: The factor analysis results for the TPACK assessment survey

\begin{tabular}{|c|c|c|c|c|}
\hline \multicolumn{2}{|c|}{ Scale } & $\begin{array}{l}\text { Exploratory } \\
\text { factor analysis } \\
\text { EFA }(\mathrm{N}=668)\end{array}$ & $\begin{array}{l}\text { Confirmatory } \\
\text { factor analysis } \\
\text { CFA }(\mathrm{N}=628)\end{array}$ & $\begin{array}{l}\text { alpha } \\
\text { value }\end{array}$ \\
\hline \multirow{4}{*}{$\begin{array}{c}\text { Web } 2.0 \text {-related } \\
\text { TK } \\
\text { (4 items) }\end{array}$} & Web 2.0-related TK 1 & .88 & .79 & \multirow{4}{*}{.90} \\
\hline & Web 2.0-related TK 2 & .86 & .80 & \\
\hline & Web 2.0-related TK 3 & .82 & .90 & \\
\hline & Web 2.0-related TK 4 & .69 & .77 & \\
\hline \multirow{9}{*}{$\begin{array}{c}\text { PK } \\
\text { (9 } \text { items) }\end{array}$} & PK1 & .79 & .90 & \multirow[t]{9}{*}{.97} \\
\hline & PK2 & .72 & .87 & \\
\hline & PK3 & .75 & .88 & \\
\hline & PK4 & .74 & .87 & \\
\hline & PK5 & .76 & .88 & \\
\hline & PK6 & .72 & .84 & \\
\hline & PK7 & .67 & .83 & \\
\hline & PK8 & .68 & .87 & \\
\hline & PK9 & .71 & .85 & \\
\hline \multirow{5}{*}{$\begin{array}{c}\text { CK } \\
\text { (5 items) }\end{array}$} & CK 1 & .84 & .88 & \multirow[t]{5}{*}{.93} \\
\hline & CK 2 & .81 & .93 & \\
\hline & CK 3 & .73 & .90 & \\
\hline & CK 4 & .76 & .69 & \\
\hline & CK 5 & .74 & .73 & \\
\hline \multirow{6}{*}{$\begin{array}{c}\text { TPK } \\
\text { (6 items) }\end{array}$} & TPK1 & .79 & .87 & \multirow[t]{6}{*}{.95} \\
\hline & TPK2 & .81 & .91 & \\
\hline & TPK3 & .82 & .92 & \\
\hline & TPK4 & .83 & .86 & \\
\hline & TPK5 & .76 & .85 & \\
\hline & TPK6 & .73 & .82 & \\
\hline \multirow{10}{*}{$\begin{array}{c}\text { TPACK } \\
\text { (10 items) }\end{array}$} & PCK 1 & .65 & .87 & \multirow[t]{10}{*}{.97} \\
\hline & PCK 2 & .66 & .88 & \\
\hline & PCK 3 & .62 & .88 & \\
\hline & PCK 4 & .61 & .87 & \\
\hline & TCK 1 & .72 & .88 & \\
\hline & TCK 2 & .74 & .87 & \\
\hline & TCK 3 & .62 & .85 & \\
\hline & TPACK 1 & .79 & .87 & \\
\hline & TPACK 2 & .75 & .86 & \\
\hline & TPACK 3 & .77 & .84 & \\
\hline
\end{tabular}

Table 3 summarises the confirmatory factor analysis (by using post-test data) results that the factor loading values for the survey items are larger than .50 and reach significance $(\mathrm{p}<.01)$. In addition, the results also reveal that values of $\mathrm{CFI}=.99$, RMSEA $=.001$, and $\chi^{2} /$ degree of freedom $=.89$, which indicate a good model fit and good convergent and construct validity of the survey items. The Cronbach alpha value for the overall survey items is .94, suggesting adequate internal consistency of the survey items. The final selected items are presented in Appendix B. 
Table 3: The factor analysis results for preservice teachers' perceived ability to guide students on cyberwellness issues survey

\begin{tabular}{|c|c|c|c|c|c|c|}
\hline \multicolumn{2}{|l|}{ Scale } & Mean & $\begin{array}{l}\text { Std } \\
\text { dev }\end{array}$ & $\begin{array}{l}\text { Exploratory factor } \\
\text { analysis (EFA) }\end{array}$ & $\begin{array}{l}\text { Confirmatory factor } \\
\text { analysis (CFA) }\end{array}$ & $\begin{array}{l}\text { alpha } \\
\text { value }\end{array}$ \\
\hline \multirow{4}{*}{$\begin{array}{c}\text { Cyberwellness } \\
\text { knowledge }(\mathrm{CW}) \\
(4 \text { items })\end{array}$} & CW 1 & \multirow[t]{4}{*}{5.57} & \multirow[t]{4}{*}{.74} & .91 & .84 & \multirow[t]{4}{*}{.94} \\
\hline & CW 2 & & & .90 & .83 & \\
\hline & CW 3 & & & .89 & .95 & \\
\hline & CW 4 & & & .89 & .92 & \\
\hline
\end{tabular}

\section{Research question 1: How effective is the ICT course in enhancing the preservice teachers' perceived understanding of the identified TPACK constructs and cyberwellness?}

To answer the first research question, the t-tests were administered to compare whether there is a significant difference between the preservice teachers' perceived understanding of TPACK and cyberwellness knowledge before and after the ICT course. Table 4 shows the pre-course and post-course survey results.

Table 4: The results of t-tests for the TPACK constructs and cyberwellness

\begin{tabular}{|c|c|c|c|c|c|}
\hline & Pre-post & Mean & Std. deviation & t-test & Effect size \\
\hline \multirow{2}{*}{$\begin{array}{l}\text { Web 2.0- } \\
\text { related TK }\end{array}$} & Pre-test & 4.92 & 1.24 & \multirow{2}{*}{$8.31^{* *}$} & \multirow[t]{2}{*}{.46} \\
\hline & Post-test & 5.39 & .74 & & \\
\hline \multirow[t]{2}{*}{ CK } & Pre-test & 4.67 & 1.05 & \multirow[t]{2}{*}{$15.02^{* *}$} & \multirow[t]{2}{*}{.83} \\
\hline & Post-test & 5.47 & .87 & & \\
\hline \multirow[t]{2}{*}{ TPK } & Pre-test & 5.93 & .77 & \multirow[t]{2}{*}{-.36} & \multirow[t]{2}{*}{-.01} \\
\hline & Post-test & 5.92 & .69 & & \\
\hline \multirow[t]{2}{*}{ PK } & Pre-test & 5.12 & .87 & \multirow[t]{2}{*}{$18.12^{* *}$} & \multirow[t]{2}{*}{1.02} \\
\hline & Post-test & 5.92 & .69 & & \\
\hline \multirow[t]{2}{*}{ TPCK } & Pre-test & 4.94 & .93 & \multirow[t]{2}{*}{$13.86^{* *}$} & \multirow[t]{2}{*}{.76} \\
\hline & Post-test & 5.55 & .64 & & \\
\hline \multirow[t]{2}{*}{$\mathrm{CW}$} & Pre-test & 4.83 & 1.13 & \multirow[t]{2}{*}{$15.13^{* *}$} & \multirow[t]{2}{*}{.83} \\
\hline & Post-test & 5.59 & .64 & & \\
\hline
\end{tabular}

The results of the t-tests indicate that five out of the six constructs (Web 2.0-related TK, PK, CK, TPCK, CW) made positive gains with medium to large effect sizes (effect size $=.46,1.02, .83, .76, .83$, respectively). The construct TPK did not achieve significant gain (Mpre=5.93, Mpost= 5.92), probably due to ceiling effects as the preservice teachers rated themselves high on this construct and the rating is consistent for the pre-and-post course. The results indicate that the course is perceived by the preservice teachers as effective in promoting changes towards more sophisticated understanding of TPACK and cyberwellness knowledge.

\section{Research question 2: Is the hypothesised structural equation model acceptable in depicting the relationships between the identified TPACK constructs and cyberwellness?}

Based on post-course survey data, Pearson's correlation analysis was used to first elicit possible relationships between cyberwellness and the identified five TPACK factors (TPACK, Web 2.0-related TK, CK, TPK, PK). The five TPACK constructs are significantly and positively related to the cyberwellness factor $(r=.75, .61, .66, .63, .76$, 
respectively). That is, the increase in TPACK perceptions is associated with the increase in the teachers' instructional capability on cyberwellness issues, and vice versa. On the other hand, the five factors of the TPACK survey are also significantly and positively correlated with each other. There are strong and positive relationships between TPK and Web 2.0-related TK; TPK and CK; TPK and PK with the correlation coefficient ranged from .50 to .70, between Web 2.0-related TK and CK; Web 2.0-related TK and PK $(r=.53, .56$, respectively), and between PK and CK $(r=.64)$.

\section{Structural equation modeling analysis}

Structural equation modeling (SEM) was utilised to examine the structural relations among the TPACK constructs and cyberwellness based on the post-course survey results. The hypothesised relationship between each construct was proposed in Figure 1. A summary of the maximum likelihood parameter estimates (completed standard coefficients) and their significance (as indicated by asterisks, $p<.01$ ) is depicted in Figure 2. Paths without statistical significance are omitted in Figure 2. According to Figure 2, CK and PK are both significant positive predictors in explaining the variation of the TPACK knowledge (path coefficients = .19 and .61, respectively) while Web 2.0related TK and PK are the significantly positive predictors of TPK (path coefficients = .14 and .52, respectively). The cyberwellness factor is also a statistically positive predictor to TPK and TPACK constructs (path coefficients $=.13$ and .15 , respectively, $p$ $<.01$ ). Finally, the values of CFI $=.96$, RMSEA $=.05$, and $\chi^{2} /$ degree of freedom $=2.40$ indicate an adequate model fit for the SEM analysis.

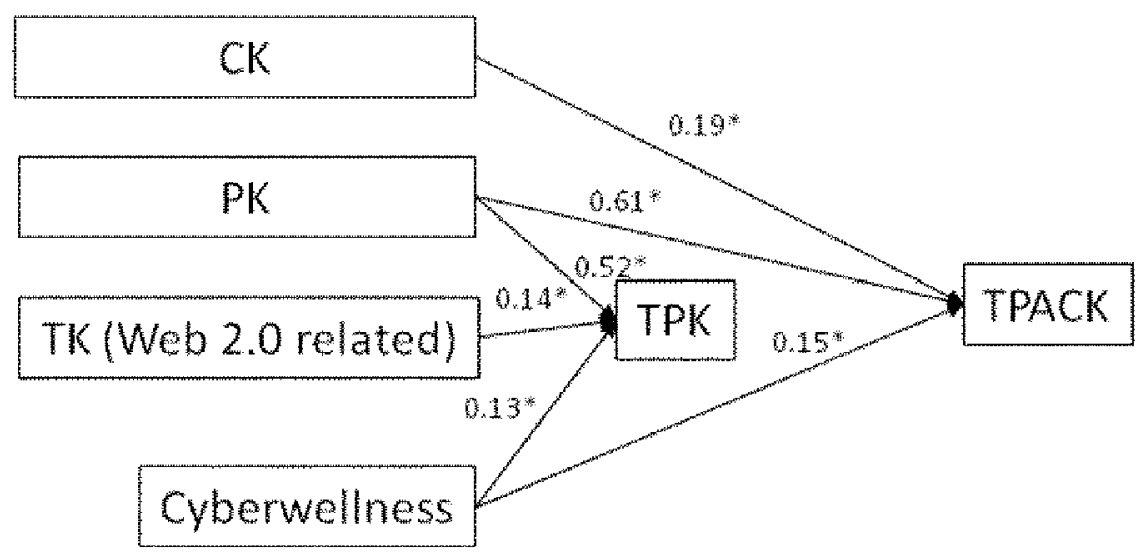

Figure 2: The final model of structural relations among content, pedagogy, web-related technology knowledge, and cyberwellness constructs. $\left({ }^{*} p<.01\right)$

In summary, only the preservice teachers' CK and PK perceptions have directly fostered their TPACK knowledge perception. Their perceived PK and Web 2.0-related TK have direct effects with respect to their perception of TPK. Finally, the preservice teachers' ability to include cyberwellness issues in their instruction plays a direct role in facilitating these teachers' TPK and TPACK. No direct relationship is established between the teachers' perceived competence of TPK and TPACK. 


\section{Discussion}

This study was conducted to examine whether this ICT course was effective in enhancing teachers' TPACK and cyberwellness knowledge. The current study also investigated the relationships between preservice teachers' perceived understanding of TPACK and cyberwellness knowledge after taking an ICT course. Based on the findings we obtained, the following sections discuss methodological issues pertaining to surveying preservice teachers' TPACK, and pedagogical issues pertaining to course design for enhancing preservice teachers' ability to integrate meaningful use of webbased technologies with consideration about cyberwellness issues.

\section{Methodological issues}

With regards to methodological issues, the study adopted Chai et al.'s (2011) and Schmidt et al.'s (2009) instruments to assess the preservice teachers' understanding of TPACK. Based on the pre-course survey factor analysis, the TPACK survey shows that the survey items loaded on the dimensions of CK, Web 2.0-related TK, PK, TPK, and TPACK. The finding of these five factors supports previous research, namely that more contextualised items (e.g. PK, TPK) may have better identification of the TPACK components (e.g. Chai et al., 2011). In addition, the identification of the cyberwellness dimension in this study may provide future research pertaining to teacher training of ICT a tool to assess teachers' growth in this aspect.

On the other hand, the assessed items of TCK (e.g. I can use appropriate Web 2.0 technologies to represent the curricular content) and PCK (e.g. I know how to select effective teaching approaches to guide student thinking and learning in the content knowledge) are found to be loaded with the items of TPACK knowledge construct (e.g. I can use strategies that combine content, technologies, and teaching approaches that I learned about in my coursework). The explanation for the merging of TCK, PCK, and TPACK may come from the fact that, from the preservice teachers' perspective, the adoption of the Web 2.0 technologies to represent the subject matter is emerging as one of the common instructional practices for teaching the subject matter. As a result, it made content, pedagogy, and technologies less readily separated when the web context is considered (Archambault \& Barnett, 2010). As such, they are unable to distinguish between the constructs, which is a common phenomenon reported in the literature for both preservice and inservice teachers (see Archambault \& Barnett, 2010; Lee \& Tsai, 2010; Chai et al., 2011). Future research can further contextualise the current survey especially for the PCK and TCK constructs. The items of measuring the constructs should also be improved (see Cox \& Graham, 2009). We believe that TPACK surveys for specific subject matter learning would be able to identify all seven factors and therefore allow researchers to gain further insights into how they are related. We were unable to contextualise the survey to that level, as we conduct the course as a general ICT course catering for all preservice teachers.

Associated with the methodological issue of the merging of factors mentioned above is a pedagogical design issue. Clark (2001) asserted that distinguishing the difference between "delivery technology" and "instructional technology" in pedagogical design for specific learning contexts contributes to the learning achievement. Thus, the confusion of TCK and PCK may lead to unfavourable pedagogical design specifically in the web-based learning context. For example, teachers may encourage students to use blogs to communicate with one another on certain curriculum topics as the 
instructional practice and believe this practice will generate learning. However, this belief may make them ignore the pedagogical scaffolds that have to be set up, and it eventually impedes the learning outcome (e.g. Mayer, Mautone \& Prothero, 2002). Future ICT curriculum should help the preservice teacher to develop the ability to distinguish between TCK and PCK. This will help the preservice teachers to pay attention to the development of appropriate technological representations of content knowledge (TCK) and design pedagogically sound activities (PCK) to enhance students' learning. We will propose later a practcal way how this may be achieved.

\section{Pedagogical issues}

With regards to the pedagogical issues, the findings from the t-tests generally support the effectiveness of the designed ICT course in enhancing preservice teachers' knowledge and abilities to integrate the Web 2.0 technologies with their pedagogical strategies of facilitating meaningful learning. It provides further evidence that engaging preservice teachers to learn by design can help to build their capacity to integrate technology in the classroom (see also Angeli \& Valanides, 2009; Chai et al, 2011; Mishra \& Koehler, 2006; Tee \& Lee, 2011). This study extends research on TPACK by incorporating the cyberwellness dimension, and documents that it is possible and beneficial to include cyberwellness topics for preservice teachers, when they are engaged in designing web-based learning packages. The direct implication of this study is that learning by design should continue to be a main pedagogical approach to help preservice teachers to make sense and connect Web 2.0-related TK, PK and CK into meaningful lessons. It is also beneficial to include consideration of cyberwellness as an element of ICT courses, to equip the preservice teachers with the necessary awareness and skills to avoid some undesirable outcomes when engaging students in web-based learning.

The findings from the correlation analysis show that there is a significant and positive correlation between each TPACK knowledge construct, and between the construct and cyberwellness knowledge. Furthermore, the SEM results show that preservice teachers' ability to integrate cyberwellness issues into their pedagogical practices makes significant positive contributions to their TPK and TPACK. In other words, the preservice teachers believe that their abilities in integrating Web 2.0 technologies into pedagogical methods will be enhanced if they are more capable ar teaching cyberwellness knowledge. They also perceive that the more cyberwellness knowledge they possess, the better the TPACK knowledge they can develop. The findings support previous research indicating that teachers are more comfortable and skillful in integrating Internet materials into their classroom instruction after receiving training on e-safety issues (e.g. Chou \& Peng, 2011).

In this study, the cyberwellness issue is not taught explicitly. Instead, preservice teachers were provided with web and print based resources for self-directed learning and they discussed the issues online. They were required also to design lessons to address cyberwellness concerns. This could explain the small but significant coefficients between CW, TPK and TPACK. Our assessment reveals that the preservice teachers were able to identify four to five main threats as reviewed earlier and for each threat, they were able to articulate preventive measures ( e.g. setting up rules, conducting parental talks and installing filtering software) and in actions to carry out in class ( e.g. practicing good classroom management strategies and using monitoring software). We therefore argue that incorporating cyberwellness education in ICT 
courses is an economical approach and ICT courses can provide an appropriate context for the preservice teachers to consider the cyberwellness issues as they are designing ICT-integrated lessons.

The amount of curriculum time to be devoted to cyberwellness issues in teacher education programs is an important pedagogical decision for teacher educators. We suggest that the decision should be based on several factors, such as how pervasively web-based technology is being used; the curriculum time allocated for the ICT course; and reports of school students' online behaviour in the country or the school districts involved. This study's focus on cyberwellness issues can be regarded as minimal, targeting only at the awareness level. More in-depth study on cyberwellness issues may be desirable for preservice teachers.

Notwithstanding some positive outcomes from this course, the SEM analysis results indicated that only PK and CK associated positively with the preservice teachers' TPACK. This finding is consistent with the previous research showing that teachers with better pedagogical and content knowledge had superior performance in applying technology to their teaching, after attaining ICT training (Guzey \& Roehrig, 2009). In addition, the SEM result also supports that teachers' Web 2.0-related TK and PK positively relate to their perception of TPK. Nevertheless, the present study failed to establish the structural relationships between Web 2.0-related TK and TPACK as well as between TPK and TPACK. Together with earlier discussion about the merging of factors, it indicates that the course as it is currently designed needs further improvement. More explicit links between the constructs have to be made during the instruction.

One possible way forward is to teach the TPACK framework explicitly, and subsequently formulate instructional analyses and planning processes based on the framework. Currently, while the course structure is based on the TPACK framework, the content of the course did not explicitly deal with TPACK framework. In the future, it may be advisable to teach the framework explicitly to the preservice teachers as a form of analytical and instructional planning framework. Table 5 below shows our initial attempt to synthesise the TPACK framework with Reiser and Dick's (1996) instructional planning guide for teachers. We propose that an ICT course could introduce the TPACK framework explicitly, to build preservice teachers' awareness of the various types of knowledge needed for an ICT integrated lesson. After the initial introduction, Table 5 with its TPACK design scaffolds could be employed to guide preservice teachers in the lesson design processes. We formulated the TPACK design scaffolds as guiding questions, as we see the questions as important considerations that could help preservice teachers to pay attention to the various aspects of TPACK knowledge and make better informed decisions.

For example, in the context of Singapore's current policy that emphasises the use of ICT for self-directed and collaborative learning, teachers should think consciously about how students' abilities in managing their own learning and their ability to communicate and co-construct knowledge could be enhanced in the course of learning the subject matter. These abilities are now regarded as important 'soft' skills for the 21st century. A design scaffold is therefore added in the PK column to draw the teachers' attention. Another example of TPACK design scaffold worth noting is the inclusion of considerations about cyberwellness issues in the TPK column. As we argue earlier, cyberwellness knowledge is a unique form of TPK. Through conscious consideration of the various TPACK design scaffolds provided, the preservice teacher's ability to 
distinguish the constructs and their competency in designing more comprehensive lessons could be further enhanced. We have begun some formative investigation on the usefulness of the lesson design guide for both preservice and inservice teachers.

Table 5: Lesson design guide ICT integrated lesson

\begin{tabular}{|c|c|c|c|c|c|c|c|}
\hline $\begin{array}{l}\text { Instructional } \\
\text { planning } \\
\text { process }\end{array}$ & \multicolumn{3}{|c|}{$\begin{array}{l}\text { Identifying goals (demands from } \\
\text { syllabi, school and/or Ministry policy }\end{array}$} & \multirow{2}{*}{\begin{tabular}{|l|}
\multicolumn{1}{|c|}{$\begin{array}{c}\text { Analysing } \\
\text { learners }\end{array}$} \\
Pedagogical \\
content \\
knowledge
\end{tabular}} & \multicolumn{2}{|c|}{$\begin{array}{l}\text { Choose media/ } \\
\text { ICT-based resource }\end{array}$} & \multirow{2}{*}{\begin{tabular}{|c|}
$\begin{array}{c}\text { Plan } \\
\text { instructional } \\
\text { activities }\end{array}$ \\
TPACK
\end{tabular}} \\
\hline $\begin{array}{l}\text { TPACK } \\
\text { dimensions }\end{array}$ & $\begin{array}{l}\text { Content } \\
\text { knowledge }\end{array}$ & $\begin{array}{l}\text { Pedagogical } \\
\text { knowledge }\end{array}$ & $\begin{array}{l}\text { Technological } \\
\text { knowledge }\end{array}$ & & $\begin{array}{l}\text { Technological } \\
\text { content } \\
\text { knowledge }\end{array}$ & \begin{tabular}{|l|} 
Technological \\
pedagogical \\
knowledge
\end{tabular} & \\
\hline $\begin{array}{l}\text { TPACK } \\
\text { design } \\
\text { scaffolds }\end{array}$ & $\begin{array}{l}\text { What are the } \\
\text { targeted } \\
\text { attitudes, } \\
\text { skills and } \\
\text { knowledge } \\
\text { that students } \\
\text { should learn } \\
\text { for the } \\
\text { specific } \\
\text { subject } \\
\text { matter? }\end{array}$ & $\begin{array}{l}\text { What are } \\
\text { some general } \\
\text { pedagogical } \\
\text { requirements? } \\
\text { (e.g. the } \\
\text { inclusion of } \\
\text { self-directed } \\
\text { learning, } \\
\text { collaborative } \\
\text { learning, } \\
\text { knowledge } \\
\text { creation, etc). }\end{array}$ & $\begin{array}{l}\text { What are some } \\
\text { possible } \\
\text { content-free } \\
\text { general } \\
\text { software/ } \\
\text { hardware } \\
\text { available that } \\
\text { may be } \\
\text { associated with } \\
\text { the identified } \\
\text { CK? }\end{array}$ & $\begin{array}{l}\text { Who is facing } \\
\text { what types of } \\
\text { problems in } \\
\text { learning the CK } \\
\text { given what } \\
\text { types of envir- } \\
\text { onment? What } \\
\text { are the existing } \\
\text { pedagogical } \\
\text { practices } \\
\text { associated with } \\
\text { the teaching of } \\
\text { the subject } \\
\text { matter? }\end{array}$ & $\begin{array}{l}\text { What are the } \\
\text { available forms } \\
\text { of technology } \\
\text { or computer- } \\
\text { based repres- } \\
\text { entations of } \\
\text { CK? How does } \\
\text { the expert/ } \\
\text { practitioner } \\
\text { use technology } \\
\text { to represent } \\
\text { and make } \\
\text { meaning of the } \\
\text { CK? }\end{array}$ & $\begin{array}{l}\text { What are the } \\
\text { associated } \\
\text { pedagogical } \\
\text { approaches } \\
\text { for the forms } \\
\text { of identified } \\
\text { TK/TCK? Any } \\
\text { consideration } \\
\text { for } \\
\text { cyberwellness } \\
\text { issues? }\end{array}$ & $\begin{array}{l}\text { How can the } \\
\text { preceding } \\
\text { dimensions } \\
\text { be } \\
\text { synthesised } \\
\text { to optimise } \\
\text { students' } \\
\text { understanding } \\
\text { and/ or } \\
\text { knowledge } \\
\text { construction? }\end{array}$ \\
\hline Decisions & \multicolumn{4}{|c|}{ Formulate the lesson objectives } & \multicolumn{3}{|c|}{$\begin{array}{l}\text { Articulate on resources, grouping instruction } \\
\text { (single, pair,, etc), technologies, approaches } \\
\text { (problem-based, project-based, inquiry- } \\
\text { based, etc), procedures, assessment, } \\
\text { classroom management strategies, etc. }\end{array}$} \\
\hline $\begin{array}{l}\text { Follow up } \\
\text { action }\end{array}$ & \multicolumn{7}{|c|}{ Implementation $\rightarrow$ Reflection $\rightarrow$ Revision } \\
\hline
\end{tabular}

Finally, Angeli and Valanides (2009) argued that the growth or proficiency of each TPACK knowledge construct does not automatically increase the educator's overall TPACK knowledge. Instead, a thorough transformation of these constructs contributes to the growth of the TPACK. Taken together, the findings generated by this study support the transformative view of TPACK development and identify the possibility that teachers' confidence to teach cyberwellness knowledge plays an important role during this transformative process.

\section{Conclusion}

This study investigated the effectiveness of a Singaporean preservice ICT course based on five identified TPACK knowledge constructs (PK, CK, Web 2.0-related TK, TPK, TPACK) and the teachers' cyberwellness knowledge (CW) as another distinctive construct. The pre-post course surveys indicate that the preservice teachers perceived strong gains in 5 out 6 constructs measured. Furthermore, structural equation modeling confirmed that cyberwellness knowledge contributes significantly to TPK and TPACK.

Based on these results, a planning guide was formulated as a means to facilitate teachers' planning of ICT integrated lessons with consideration given to cyberwellness issues. We suggest that future design experiments for both preservice and inservice teachers should be carried out to test and refine the planning guide and other similar devices that could help to build teachers' TPACK design capacity, in tackling the wicked problem of integrating ICT into curriculum. 


\section{References}

AACTE (Ed.) (2008). Handbook of technological pedagogical content knowledge (TPCK) for educators. New York: Routledge.

Ajjan, H. \& Hartshorne, R. (2008). Investigating faculty decisions to adopt Web 2.0 technologies: Theory and empirical tests. The Internet and Higher Education, 11(2), 71-80. http:// dx.doi.org/10.1016/j.iheduc.2008.05.002

Angeli, C. \& Valanides N. (2009). Epistemological and methodological issues for the conceptualization, development, and assessment of ICT-TPCK: Advances in technological pedagogical content knowledge (TPCK). Computers $\mathcal{E}$ Education, 52(1), 154-168. http:// dx.doi.org/10.1016/j.compedu.2008.07.006

Archambault, L. M. \& Barnett, J. H. (2010). Revisiting technological pedagogical content knowledge: Exploring the TPACK framework. Computers $\mathcal{E}$ Education, 55(4), 1656-1662. http:/ / dx.doi.org/10.1016/j.compedu.2010.07.009

Archambault, L., Wetzel, K., Foulger, T. S. \& Williams, M.K. (2010). Professional development 2.0: Transforming teacher education pedagogy with 21st century tools. Journal of Digital Learning in Teacher Education, 27(1), 4-11. http:/ / 20.132.48.254/ERICWebPortal/ content delivery / servlet $/$ ERICServlet?accno=EJ898518

Beycioglu, K. (2009). A cyberphilosophical issue in education: Unethical computer using behavior - The case of prospective teachers. Computers $\mathcal{E}$ Education, 53(2), 201-208. http:/ / dx.doi.org/10.1016/j.compedu.2009.01.009

Bull, G., Hammond, T. \& Ferster, B. (2008). Developing Web 2.0 tools for support of historical inquiry in social studies. Computers in the School, 25(3-4), 275-287. http: / / dx.doi.org/10.1080/07380560802367761

Bulter, K. (2010). Cybersafety in the classroom. District Administration Magazine, June, 53-57. http: / / www.districtadministration.com/article/ cybersafety-classroom

Bumgardner, S. \& Knestis, K. (2011). Social networking as a tool for student and teacher learning. District Administration Magazine, May, 85-86.

http: / / www.districtadministration.com/article/ social-networking-tool-student-andteacher-learning

Chai, C. S. (2011). A review of research employing technological pedagogical content knowledge (TPACK) as framework for ICT use in teaching and learning. Paper presented at Edutainment 2011. September, Taipei, Taiwan.

Chai, C. S., Koh, J. H. L. \& Tsai, C.-C. (2010). Facilitating preservice teachers' development of technological, pedagogical, and content knowledge (TPACK). Educational Technology $\mathcal{E}$ Society, 13(4), 63-73. http:/ / www.ifets.info/journals/13_4/7.pdf

Chai, C. S., Koh, J. H. L., Tsai, C.-C. \& Tan, L. L. W. (2011). Modeling primary school pre-service teachers' technological pedagogical content knowledge (TPACK) for meaningful learning with information and communication technology (ICT). Computers $\mathcal{E}$ Education, 57(1), 11841193. http:/ / dx.doi.org/10.1016/j.compedu.2011.01.007

Cheon, J., Song, J., Jones, R. D. \& Nam, K. (2010). Influencing preservice teachers' intention to adopt Web 2.0 services. Journal of Digital Learning in Teacher Education, 27(2), 53-64. http: / / www.iste.org/ store/ product.aspx?ID=1727

Chou, C. \& Peng, H. (2011). Promoting awareness of Internet safety in Taiwan in-service teacher education: A ten-year experience. The Internet and Higher Education, 14(1), 44-53. http: / / dx.doi.org/10.1016/j.iheduc.2010.03.006 
Clark, R. E. (2001). Learning with media: Arguments, analysis and evidence. Connecticut: Information Age Publishing Inc.

Cox, S. \& Graham, C. R. (2009). Diagramming TPCK in practice: Using an elaborated model of the TPCK framework to analyze and depict teacher knowledge. TechTrends, 53(5), 60-69. http: / / dx.doi.org/10.1007/ s11528-009-0327-1

Doering, A., Veletsianos, G., Scharber, C. \& Miller, C. (2009). Using the technological, pedagogical, and content knowledge framework to design online learning environments and professional development. Journal of Educational Computing, 41(3), 319-346. http:/ / dx.doi.org/10.2190/EC.41.3.d

Dohn, N. B. (2009). Web 2.0: Inherent tensions and evident challenges for education. International Journal of Computer-Supported Collaborative Learning, 4(3), 343-363. http: / / dx.doi.org/10.1007/ s11412-009-9066-8

Endicott-Popovsky, B. E. (2008). Unintended consequences of the information age: Our children at risk. Paper presented at a workshop at the meeting of the Washington Library Media Association, October, Pasco, WA.

Greenhow, C., Robelia, B. \& Hughes, J. E. (2009). Web 2.0 and classroom research: What path should we take now? Educational Researcher, 38(4), 246-259. http: / / dx.doi.org/10.3102/0013189X09336671

Grosseck, G. (2009). The use or not to use Web 2.0 in higher education? Procedia Social and Behavioral Sciences, 1(1), 478-482. http:/ / dx.doi.org/10.1016/j.sbspro.2009.01.087

Guzey, S. S. \& Roehrig, G. H. (2009). Teaching science with technology: Case studies of science teachers' development of technology, pedagogy, and content knowledge. Contemporary Issues in Technology and Teacher Education, 9(1), 25-45. http: / / editlib.org/d/29293

Hair, J. F., Black, W. C., Babin, B. J., Anderson, R. E. \& Tatham, R. L. (2006). Multivariate data analysis (6th ed.). New York: Prentice Hall.

Hartshorne, R. \& Ajjan, H. (2009). Examining student decisions to adopt Web 2.0 technologies: theory and empirical tests. Journal of Computing in Higher Education, 21(3), 183-198. http: / / dx.doi.org/ 10.1007/ s12528-009-9023-6

Jimoyiannis, A. (2010). Designing and implementing an integrated technological pedagogical science knowledge framework for science teachers professional development. Computers $\mathcal{E}$ Education, 55(3), 1259-1269. http: / / dx.doi.org/10.1016/j.compedu.2010.05.022

Jonassen, D., Howland, J., Marra, R. \& Crismond, D. (2008). Meaningful learning with technology (3rd ed.). Upper Saddle River, NJ: Pearson.

Koehler, M. J. \& Mishra, P. (2005). Teachers learning technology by design. Journal of Computing in Teacher Education, 21(3), 94-102. http: / / creativity.fts.educ.msu.edu/wpcontent/uploads/2011/09/Teachers-Learning-Technology-by-Design.pdf

Land, R. \& Bayne, S. (2008). Social technologies in higher education: Authorship, subjectivity and temporality. Proceedings of the 6th International Conference on Networked Learning, 675-681. http:/ / www.networkedlearningconference.org.uk/past/nlc2008/abstracts/PDFs / Land_675-681.pdf

Lee, M. H. \& Tsai, C. C. (2010). Exploring teachers' perceived self efficacy and technological pedagogical content knowledge with respect to educational use of the world wide web. Instructional Science, 38(1), 1-21. http: / / dx.doi.org/10.1007/ s11251-008-9075-4 
Lim, W. Y. (2010). Cybersafety in the face of 21st century learning. In C. S. Chai \& Q. Wang (Eds.), ICT for self-directed and collaborative learning (pp. 127-139). Singapore: Pearson.

Marino, M. T., Sameshima, P. \& Beecher, C. C. (2009). Enhancing TPACK with assistive technology: Promoting inclusive practices in preservice teacher education. Contemporary Issues in Technology and Teacher Education, 9(2).

http:// www.citejournal.org/vol9/iss2/general/article1.cfm

Maranto, G. \& Barton, M. (2010). Paradox and promise: Myspace, Facebook, and the sociopolitics of social networking in the writing classroom. Computers and Composition, 27(1), 36-47. http: / / dx.doi.org/10.1016/j.compcom.2009.11.003

Mayer, R. E., Mautone, P. \& Prothero, W. (2002). Pictorial aids for learning by doing in a multimedia geology simulation game. Journal of Educational Psychology, 94(1), 171-185. http: / / psycnet.apa.org / index.cfm?id=2002-02073-016

Mishra, P. \& Koehler M. J. (2006). Technological pedagogical content knowledge: A framework for teacher knowledge. Teachers College Record, 108(6), 1017-1054. http: / / www.tcrecord.org/Content.asp?ContentID=12516

Neal, L. \& Miller, D. (2006). The use of technology in education. Web-based learning: theory, research, and practice. Mahwah, NJ: Lawrence Erlbaum Associates.

Nelson, J. Christopher, A. \& Mims, C. (2009). TPACK and Web 2.0: Transformation of teaching and learning. TechTrends, 53(5), 80-85. http: / / dx.doi.org/10.1007/ s11528-009-0329-z

Pierson, M. \& Borthwick, A. (2010). Framing the assessment of educational technology professional development in a culture of learning. Journal of Digital Learning in Teacher Education, 26(4), 126-131. http: / / www.iste.org/Store/Product.aspx?ID=1243

Purdy, P. J. (2010). The changing space of research: Web 2.0 and the integration of research and writing environments. Computers and Composition, 27(1), 48-58. http:/ / dx.doi.org/10.1016/j.compcom.2009.12.001

Reiser, R. A. \& Dick, W. (1996). Instructional planning: A guide for teachers (2nd ed.). Boston: Allyn \& Bacon.

Schmidt, A. D., Baran, E., Thompson, A. D., Mishra, P., Koehler, M. J. \& Shin, T. S. (2009). Technological pedagogical content knowledge (TPACK): The development and validation of an assessment instrument for preservice teachers. Journal of Research on Technology in Education, 42(2), 123-149. http: / / www.iste.org/ store/Product.aspx?ID=1133

Sharples, M., Graber, R., Harrison, C. \& Logan, K. (2009). E-safety and Web 2.0 for children aged 11-16. Journal of Computer Assisted Learning, 25(1), 70-84. http:/ / dx.doi.org/10.1111/j.13652729.2008.00304.x

Shulman, L. S. (1986). Those who understand: Knowledge growth in teaching. Educational Researcher, 15(2), 4-14. http:/ / dx.doi.org/10.3102/0013189X015002004

So, H. \& Kim, B. (2009). Learning about problem based learning: Student teachers integrating technology, pedagogy and content knowledge. Australasian Journal of Educational Technology, 25(1), 101-116. http: / / www.ascilite.org.au/ajet/ ajet25/ so.html

Tee, M. \& Lee, S. (2011). From socialisation to internalisation: Cultivating technological pedagogical content knowledge through problem-based learning. Australasian Journal of Educational Technology, 27(1), 89-104. http:/ / www.ascilite.org.au/ajet/ajet27/ tee.html 
Valcke, M., Schellens, T., Keer, H. V. \& Gerarts, M. (2007). Primary school children's safe and unsafe use of the Internet at home and at school: An exploratory study. Computers in Human Behavior, 23(6), 2838-2850. http:/ / dx.doi.org/10.1016/j.chb.2006.05.008; also at http: / / users.ugent.be/ mvalcke/CV/vecits.pdf

Wang, Q. \& Woo, H. L. (2009). Exploring the use of Web 2.0 tools to support collaborative learning. Journal of Education Research, 3(3), 191-202.

Wishart, J. (2004). Internet safety in emerging educational contexts. Computers $\mathcal{E}$ Education, 43(12), 193-204. http: / / dx.doi.org/10.1016/j.compedu.2003.12.013

\section{Appendix A: The TPACK for Meaningful Learning Survey}

\begin{tabular}{|c|c|}
\hline \multicolumn{2}{|l|}{ Items } \\
\hline \multicolumn{2}{|l|}{ Web 2.0-related TK (4 items) } \\
\hline I am able to use Web 2.0 (e.g blog, wiki, Facebook) for personal purpose & TK1 \\
\hline I am able to teach my student to use web 2.0 tools (e.g. blog, wiki, Facebook). & TK2 \\
\hline $\begin{array}{l}\text { I am able to integrate the use of Web } 2.0 \text { tools (e.g blog, wiki, Facebook) for } \\
\text { students' learning. }\end{array}$ & TK3 \\
\hline $\begin{array}{l}\text { I am able to use conferencing software (Yahoo, IM, MSN Mesenger, ICQ, Skype, } \\
\text { etc) for collaboration purposes. }\end{array}$ & TK4 \\
\hline \multicolumn{2}{|l|}{ PK (9 items) } \\
\hline I teach my students to adopt appropriate learning strategies. & PK1 \\
\hline $\begin{array}{l}\text { I know how to guide my students to get along with each other during group } \\
\text { work. }\end{array}$ & PK2 \\
\hline I guide my student to build on each other's ideas while working in groups. & PK3 \\
\hline I know how to guide my students to discuss effectively during group work. & PK4 \\
\hline I conduct activities that require students to work with each other. & PK5 \\
\hline I teach my students to monitor their own learning. & PK6 \\
\hline I know how to guide my student to learn independently. & PK7 \\
\hline $\begin{array}{l}\text { I encourage my students to make use of available resources for their own } \\
\text { learning. }\end{array}$ & PK8 \\
\hline I am able to plan group activities for my students. & PK9 \\
\hline \multicolumn{2}{|l|}{ CK (5 items) } \\
\hline I can think about the subject matter like an expert who specialise in my CS2. & CK1 \\
\hline I have sufficient knowledge about my CS 2. & CK2 \\
\hline I have various ways and strategies of developing my understanding of my CS2. & CK3 \\
\hline I can think about the subject matter like an expert who specialise in my CS1. & CK4 \\
\hline I have sufficient knowledge about my CS 1. & CK5 \\
\hline \multicolumn{2}{|l|}{ TPK (6 items) } \\
\hline I will encourage my students to use the computers to do group presentation. & TPK1 \\
\hline I will encourage my students to use the computers to work with other students. & TPK2 \\
\hline $\begin{array}{l}\text { I will encourage my students to use the computers to analyse information with } \\
\text { their classmates. }\end{array}$ & TPK3 \\
\hline $\begin{array}{l}\text { I will encourage my students to use the computers to find more information on } \\
\text { their own. }\end{array}$ & TPK4 \\
\hline $\begin{array}{l}\text { I will encourage my students to use the computers to communicate with other } \\
\text { people about their ideas. }\end{array}$ & TPK5 \\
\hline $\begin{array}{l}\text { I will encourage my students to use computers to practice a skill that they are } \\
\text { interested in on their own. }\end{array}$ & TPK6 \\
\hline \multicolumn{2}{|l|}{ TPACK (10 items) } \\
\hline $\begin{array}{l}\text { I can help my students to understand the content knowledge of CS2 through } \\
\text { various ways. }\end{array}$ & PCK1(a) \\
\hline $\begin{array}{l}\text { I can help my students to understand the content knowledge of CS1 through } \\
\text { various ways. }\end{array}$ & PCK2 \\
\hline
\end{tabular}




\begin{tabular}{|l|c|}
\hline $\begin{array}{l}\text { I know how to select effective teaching approaches to guide student thinking } \\
\text { and learning in my CS1 }\end{array}$ & PCK3 \\
\hline $\begin{array}{l}\text { I know how to select effective teaching approaches to guide student thinking } \\
\text { and learning in my CS2 }\end{array}$ & PCK4 \\
\hline I know about technologies that I can use for understanding and doing my CS1. & TCK1(b) \\
\hline $\begin{array}{l}\text { I can use appropriate technologies (e.g. multimedia resources, simulation) to } \\
\text { represent the content of my CS1 }\end{array}$ & TCK2 \\
\hline $\begin{array}{l}\text { I can use appropriate technologies (e.g. multimedia resources, simulation) to } \\
\text { represent the content of my CS2 }\end{array}$ & TCK3 \\
\hline $\begin{array}{l}\text { I can teach lessons that appropriately combine my CS1, technologies and } \\
\text { teaching approaches. }\end{array}$ & TPACK1 \\
\hline $\begin{array}{l}\text { I can use strategies that combine content, technologies and teaching approaches } \\
\text { that I learned about in my coursework in my classroom. }\end{array}$ & TPACK2 \\
\hline $\begin{array}{l}\text { I can select technologies to use in my classroom that enhance what I teach, how I } \\
\text { teach and what students learn. }\end{array}$ & TPACK3 \\
\hline
\end{tabular}

a: Originally designed for the PCK construct

b: Originally designed for the TCK construct

\section{Appendix B: The preservice teachers' perceived ability to guide students on cyberwellness issues survey}

I model and teach legal and ethical use of IT

\begin{tabular}{l|l} 
I am able to guide students on the safe use of the Internet & CW1
\end{tabular}

I implement classroom procedures that guide pupils' legal and ethical use of IT $\quad$ CW3

\begin{tabular}{|l|l}
\hline I am able to teach students about cyberwellness issues & CW4
\end{tabular}

Authors: Dr Ching Sing Chai, Associate Professor

Learning Sciences \& Technologies, National Institute of Education

Nanyang Technological University, 1 Nanyang Walk, Singapore 637616

Email: chingsing.chai@nie.edu.sg

Web: http://www.nie.edu.sg/profile/ chai-ching-sing

Joyce Hwee Ling Koh, Assistant Professor

Learning Sciences \& Technologies, National Institute of Education

Nanyang Technological University, 1 Nanyang Walk, Singapore 637616

Email: joyce.koh@nie.edu.sg

Web: http: / / www.nie.edu.sg/profile/koh-hwee-ling-joyce

Hsin Ning Jessie Ho, Graduate Institute of Digital Learning and Education

National Taiwan University of Science and Technology

No.43, Sec. 4, Keelung Road, Da'an District, Taipei City 106, Taiwan

Chin-Chung Tsai, Chair Professor

Graduate Institute of Digital Learning and Education

National Taiwan University of Science and Technology

No.43, Sec. 4, Keelung Road, Da'an District, Taipei City 106, Taiwan

Email: cctsai@mail.ntust.edu.tw

Web: http: / / research.hchs.hc.edu.tw/ cctsai/index_eng.html

Please cite as: Chai, C. S., Koh, J. H. L., Ho, H. N. J. \& Tsai, C.-C. (2012). Examining preservice teachers' perceived knowledge of TPACK and cyberwellness through structural equation modeling. In C. P. Lim \& C. S. Chai (Eds), Building the ICT capacity of the next generation of teachers in Asia. Australasian Journal of Educational Technology, 28(Special issue, 6), 1000-1019.

http: / / www.ascilite.org.au/ajet/ajet28/chai-cs.html 